\title{
Total Phenolic Contents and Antioxidant Potential of Soya Bean and Maize and their Beverages In vitro
}

Paul C Chikezie*

Department of Biochemistry, Imo State University, Owerri, Nigeria

${ }^{*}$ Corresponding author: Dr. Paul C Chikezie, Department of Biochemistry, Imo State University, Owerri, Nigeria, Tel: +2348038935327; E-mail: p_chikezie@yahoo.com

Received date: July 15, 2016; Accepted date: October 15, 2016; Published date: October 22, 2016

Copyright: @ 2016 Chikezie PC. This is an open-access article distributed under the terms of the Creative Commons Attribution License, which permits unrestricted use, distribution, and reproduction in any medium, provided the original author and source are credited.

Abstract
The present investigations sought to correlate the total phenolic contents (TPC) with antioxidant potential, using
in vitro antioxidant evaluation models, of unprocessed soya bean (SB) and its industrial processed beverages (SBB1
and SBB2) as well as unprocessed maize (SM) and its industrial processed beverages (MBB1 and MBB2). The TPC
and antioxidant potential of the samples were measured using standard spectrophotometric methods. The radical
scavenging capacity index (SCI50) defined the concentration, in $\mu \mathrm{g} / \mathrm{mL}$, of the sample required to scavenge $50 \%$ of
the investigated radicals. Likewise, AP50 defined the concentration, in $\mu \mathrm{gg} / \mathrm{mL}$, of the sample required to reduce $50 \%$
of ferric ion. The TPC of SB, SBB1 and SBB2 was within the range of $0.97 \pm 0.02-2.86 \pm 0.02 \mathrm{mg}$ gallic acid
equivalent per gram dry sample, and TPC of SM, MBB1 and MBB2 were in the increasing order: $\mathrm{SM}>\mathrm{MBB} 1>\mathrm{MBB} 2$.
The TPC of SB, SBB1 and SBB2 and their corresponding SCI50 against $\mathrm{NO}-, \mathrm{H}_{2} \mathrm{O}_{2}$ and $\cdot-\mathrm{OH}$ gave correlation
coefficients between the range: $-0.77227-0.338172$ units, whereas their corresponding AP50 gave a strong positive
correlation. The TPC of SM, MBB1 and MBB2 and their corresponding SCl50 against $\mathrm{NO}-, \mathrm{H}_{2} \mathrm{O}_{2}$ and $\cdot-\mathrm{OH}$ gave
correlation coefficients between the range: $0.040672-0.51799$ units, whereas their corresponding AP50 showed a
strong negative correlation. The study revealed that antioxidant potential was intertwined with the combinatorial
antioxidant peculiarities of the various samples.

Keywords: Antioxidants; Beverages; Maize; Soya bean; Total phenolic contents

\section{Introduction}

Phenolic compounds are of considerable importance in human diets because of their capacities to scavenge/neutralize cytotoxic reactive oxygen and nitrogen species (RONS) by donating electrons or hydrogen atoms to radicals [1-4]. In addition, phenolic compounds chelate transition metals such as $\mathrm{Cu}^{2+}, \mathrm{Co}^{2+}$ and importantly, $\mathrm{Fe}^{2+}$, which have been implicated in the generation of highly reactive hydroxyl radicals via the Fenton reaction [2,5]. Fruits, vegetables and beverages are the major sources of phenolic compounds and contribute to the dietary intake of natural antioxidants $[6,7]$. Phenolic compounds are generally synthesized via the pentose phosphate, phenylpropanoid and shikimate pathways $[2,8,9]$. These compounds possess aromatic rings bearing one or more hydroxyl groups and their structures may range from that of a simple phenolic molecule to that of a complex high-molecular weight polymer $[4,9,10]$. For instance, the flavonoids (including anthocyanins) and isoflavonoids bear the carbon skeleton $\mathrm{C}_{6}-\mathrm{C}_{3}-\mathrm{C}_{6}$ structure and account for more than half of over 8,000 different phenolic compounds $[1,3,6,9]$. In addition, tannins or tannic acids are water-soluble polyphenols that are present in many plant foods [11,12] and may exhibit antioxidant activity [13]. Bioactivity investigations have shown that the molecular structures, in particular, number of hydroxyl groups and nature of substituent groups in the aromatic rings of phenolic compounds are the major determinant of their antioxidant properties $[1,14]$, which is often referred to as the structure-activity relationships of phenolic compounds. The chemical diversity, classification and medicinal potential of phenolic compounds as well as their inherent toxicity concerns have exhaustively been reported [2-4,6,7,15-18].
The soya bean (Glycine max) in Europe, also called soybean in North America, is a leguminous vegetable of the pea family that is grown in the tropical, subtropical and temperate climates. High quality protein and lipids are abundant in soya bean, which qualifies it as a very nutritive plant. Accordingly, the Food and Agricultural Organization (FAO) classified the plant as an oil seed rather than a pulse [19]. The carbohydrates and energy values of soya bean have been reported [20]. Reports also showed that daily intake of processed soya bean appeared to be one of several beneficial factors responsible for the health and longevity of Japanese people [21]. Global soya bean demand is increasing, not only for use as an oil crop and feeds for livestock and aquaculture, but as a nutritious beverage for human consumption as well as feedstock for industrial materials and biofuel [22]. Soya beans are usually processed into soya-based infant formula, dairy product substitutes, meat alternatives, low-cost substitutes for meat and poultry products [23-26] as well as production of vodka. However, soya bean meals often contain anti-nutritional factors like trypsin inhibitors, saponins, phytoestrogens, glucinins, goitrogens, lectins and urease $[27,28]$. Based on recent production estimates, Brazil (90 million metric tons), United States of America (89.5 million metric tons), Argentina (52.6 million metric tons) and China (15 million metric tons) accounted for worldwide major producers of soya bean in 2014 [29].

Maize (Zea mays) or corn is a cereal crop that is grown widely throughout the world in a range of agro-ecological environment. There are about 500 species of maize exist in different colours, textures and grain shapes and sizes. Although maize is a grain crop, it is usually consumed as vegetable. The grain is rich in vitamins $\mathrm{A}, \mathrm{C}$ and $\mathrm{E}$, carbohydrates, essential minerals, dietary fiber and proteins [30]. On a large scale, maize could be processed into biofuel [30] and as a source of starch for the production alcoholic and non-alcoholic beverages as 
Page 2 of 7

well as feeds for livestock [26,30]. According to 2007 reports, FAO estimated that 158 million hectares of maize were harvested worldwide. Africa harvested 29 million hectares, of which Nigeria was the largest producer in sub-Sahara Africa [31]. The United States of America is the world largest producer of maize, followed by China, Brazil, Mexico and Argentina [30,32,33]. Maize and cornmeal are important staple foods for more than 1.2 billion people in sub-Sahara Africa. Maize can be eaten roasted, boiled or fried. Popcorn consists of kernels of certain maize varieties that explodes when heated forming fluffy pieces that are eaten as snacks.

Previous survey showed that the food, wine and agricultural products processing industries cause the generation of substantial quantities of phenolic-rich products and by-products, which could be valuable natural sources of antioxidants [1,34]. Phenolic compounds mostly present in human diets include phenolic acids, flavonoids and tannins [3,35]. Some of these products have been the subject of investigations and have proven to be sources of dietary antioxidants $[1,36]$. In view of the increasing consumption of industrial processed plant foods, either due to dietary preference or for convenience, the present investigations sought to correlate the total phenolic contents (TPC) with antioxidant potential, using in vitro antioxidant evaluation models, of unprocessed soya bean and maize with their corresponding industrial processed beverages commonly sold in Nigerian markets.

\section{Materials and Methods}

\section{Collection of samples}

The commercially available soya bean-based beverages (SBB1 and SBB2) and maize-based beverages (MBB1 and MBB2) were purchased at the Relief Market, Owerri, Imo State, Nigeria. The manufacturer's label showed that the beverages were within 30 days shelf-life from the date of production. Soya bean (SB) and the sweet corn variety (SM) $(Z$. mays var. saccharata) were harvested during the wet season, on the $16^{\text {th }}$ of August, 2015, from Ofkaja Farm at Uruagu-Nnewi, Anambra State (Latitude $6^{\circ} 20^{\prime} \mathrm{N}$; Longitude $7^{\circ} 00^{\prime} \mathrm{E}$ ), Nigeria, which lies on the rainforest belt. The samples were transported to the laboratory within $24 \mathrm{~h}$, identified and authenticated by Dr. Mbagwu at the Herbarium of the Department of Plant Science and Biotechnology, Imo State University, Owerri, Nigeria. The samples have voucher numbers IMSUH 223 and IMSUH 198 for the SB and SM, respectively.

\section{Compositions of beverages}

The major compositions of SBB1, SBB2, MBB1 and MBB2 according to the manufacturers' labels are presented in Table 1.

\begin{tabular}{|c|c|}
\hline Samples & Compositions/ingredients per $100 \mathrm{~g}$ \\
\hline SBB1 & Carbohydrates $(65.5 \mathrm{~g})$, protein $(13.0 \mathrm{~g})$, fat $(6.6 \mathrm{~g})$, dietary fiber $(7.2 \mathrm{~g})$, sodium (580 mg), iron (9.0 mg), calcium (455 mg), vitamin A (1166 IU). \\
\hline SBB2 & $\begin{array}{l}\text { Carbohydrates }(64.2 \mathrm{~g}) \text {, protein }(15.0 \mathrm{~g}) \text {, fat }(9.0 \mathrm{~g}) \text {, dietary fiber }(7.0 \mathrm{~g}) \text {, sodium }(210 \mathrm{mg}) \text {, potassium }(570 \mathrm{mg}) \text {, calcium }(400 \mathrm{mg}) \text {, phosphorus } \\
(260 \mathrm{mg}) \text {, linoleic acid }(3.4 \mathrm{~g}) \text {, vitamin } \mathrm{A}(1500 \mathrm{IU}) \text {, ash }(2.3 \mathrm{~g})\end{array}$ \\
\hline MBB1 & $\begin{array}{l}\text { Carbohydrates }(80.0 \mathrm{~g}) \text {, protein }(7.5 \mathrm{~g}) \text {, fat }(0.8 \mathrm{~g}) \text {, dietary fiber }(3.0 \mathrm{~g}) \text {, sodium }(0.7 \mathrm{~g}) \text {, iron }(14.0 \mathrm{mg}) \text {, vitamin A }(450 \mu \mathrm{g}) \text {, vitamin B1 }(1.2 \mathrm{mg}) \text {, } \\
\text { vitamin B2 }(1.3 \mathrm{mg}) \text {, vitamin B6 }(1.5 \mathrm{mg}) \text {, vitamin B12 }(0.85 \mu \mathrm{g}) \text {, folic acid }(190 \mu \mathrm{g}) \text {. }\end{array}$ \\
\hline MBB2 & $\begin{array}{l}\text { Carbohydrates }(85.0 \mathrm{~g}) \text {, protein }(6.0 \mathrm{~g}) \text {, fat }(1.1 \mathrm{~g}) \text {, sodium }(270 \mathrm{mg}) \text {, iron }(16 \mathrm{mg}) \text {, phosphorous }(140 \mathrm{mg}) \text {, zinc }(7.0 \mathrm{mg}) \text {, vitamin } \mathrm{C}(50.0 \mathrm{mg}) \text {, } \\
\text { vitamin } \mathrm{D}(8.5 \mathrm{\mu g}) \text {, niacin }(7.0 \mathrm{mg}) \text {, vitamin } \mathrm{E}(5.0 \mathrm{mg}) \text {, pantothenic acid }(3.1 \mathrm{mg}) \text {, thiamin }(0.50 \mathrm{mg}) \text {, vitamin } \mathrm{A}(608 \mu \mathrm{g}) \text {, folic acid }(80 \mu \mathrm{g}) \text {. }\end{array}$ \\
\hline
\end{tabular}

Table 1: Major compositions of soya bean- and maize-based beverages.

\section{Preparation of samples}

The grains of SB and SM were removed manually from the cobs and pods respectively. Next, samples of SB and SM as well as that of their beverages were dried separately in an oven (Gallenkamp Oven 300 plus series, England) at $60^{\circ} \mathrm{C}$ until a constant weight was achieved. The separate samples were ground into powder using the Thomas-Willey milling machine (ASTM D-3182; India). A $2.0 \mathrm{~g}$ of each ground sample was transferred into corresponding conical flasks containing 10 $\mathrm{mL}$ of $99.0 \% \mathrm{CH}_{3} \mathrm{OH}$ (BDH, U.K). The suspensions were shaken thoroughly and allowed to stand for $30 \mathrm{~min}$, after which the mixtures were filtered using Whatman № 1 filter paper. The extracts were concentrated and recovered in a rotary evaporator (Büch Rotavapor $\mathrm{R}-200$ ) for $12 \mathrm{~h}$ at $50^{\circ} \mathrm{C}$, for each procedure, under reduced pressure [37]. The yields were calculated to be as follows: $\mathrm{SB}=12.7 \%(\mathrm{w} / \mathrm{w})$, $\mathrm{SM}=13.1 \% \quad(\mathrm{w} / \mathrm{w}), \quad \mathrm{SBB} 1=11.6 \% \quad(\mathrm{w} / \mathrm{w}), \quad \mathrm{SBB} 2=11.5 \% \quad(\mathrm{w} / \mathrm{w})$, $\mathrm{MBB} 1=11.8 \%(\mathrm{w} / \mathrm{w})$ and $\mathrm{MBB} 2=11.1 \%(\mathrm{w} / \mathrm{w})$. The separate extracts were reconstituted in corresponding $10 \mathrm{~mL}$ phosphate buffered saline (PBS) solution, osmotically equivalent to $100 \mathrm{~g} / \mathrm{L}$ PBS; $\mathrm{pH}=7.4$ (90.0 g $\mathrm{NaCl}, 17.0 \mathrm{Na}_{2} \mathrm{HPO}_{4} \cdot 2 \mathrm{H}_{2} \mathrm{O}$ and $2.43 \mathrm{~g} \mathrm{NaH}_{2} \mathrm{PO}_{4} \cdot 2 \mathrm{H}_{2} \mathrm{O}$ ). Portions of the individual extracts were measured for TPC. Serial dilutions of the extracts in the order of $20,40,60$ and $80 \mathrm{mg} / \mathrm{mL}$ were prepared and used for measurement of their antioxidant activities in vitro.

\section{Total phenolic content}

TPC of the extracts were determined using the Folin-Ciocalteu method as previously described [38]. A $0.1 \mathrm{~mL}$ of $20-80 \mathrm{mg} / \mathrm{mL}(\mathrm{w} / \mathrm{v})$ of the extracts were added to corresponding $1.0 \mathrm{~mL}$ of $7 \% \mathrm{Na}_{2} \mathrm{CO}_{3}$ solutions and mixed thoroughly. Next, $0.1 \mathrm{~mL}$ of Folin-Ciocalteu reagent was introduced into the mixtures. The final mixture volume was made up to $2.5 \mathrm{~mL}$ using distilled water and was allowed to stand for 90 min during intermittent shaking. The absorbance of the mixture was measured at $\chi \max =750 \mathrm{~nm}$ using a spectrophotometer (Digital Blood Analyzer; SPECTRONIC 20; Labtech, LabX, Bay Street, Midland, ON, Canada). The TPC of the samples were obtained by comparing the absorbance with that of standard gallic acid calibration curve, and expressed as milligram of gallic acid equivalent per gram (mg GAE/g) of dry weight of the extracts. 


\section{Antioxidant potential in vitro}

The antioxidant potential of the extracts, which defined the capacity of the extracts to scavenge nitric oxide radical, hydrogen peroxide, hydroxyl radical and ferric reducing antioxidant power were measured as previously described [39].

\section{Nitric oxide radical}

The procedure was according to previous methods [40] but with minor modifications. Reaction mixtures containing of $2.0 \mathrm{~mL}$ of 10 $\mathrm{mM} \mathrm{NaN}_{3}$ in phosphate buffered saline $(\mathrm{pH}=7.4)$ and $1.0 \mathrm{~mL}$ of various concentrations $(20-80 \mu \mathrm{g} / \mathrm{mL})$ of the extracts were incubated at $25^{\circ} \mathrm{C}$ for $150 \mathrm{~min}$. Next, $1.0 \mathrm{~mL}$ of $0.33 \%$ sulfanilic acid in $20 \%$ glacial $\mathrm{CH}_{3} \mathrm{COOH}$ was added to $0.3 \mathrm{~mL}$ of the incubated solution and was allowed to stand for 5 min. A $0.5 \mathrm{~mL}$ of $0.1 \% \quad(\mathrm{w} / \mathrm{v})$ napthylethylenediamine dihydrochloride was added to the mixture and incubated at $25^{\circ} \mathrm{C}$ for $30 \mathrm{~min}$. The absorbance was measured at $\lambda_{\max }=540 \mathrm{~nm}$ using quercetin as blank [37]. The nitric oxide scavenging capacity index (NOSCI) of the extracts was calculated thus:

$$
\text { NOSCI } \%=\left(1-\frac{\text { Absorbance }_{\text {Test }}}{\text { Absorbance }_{\text {Blank }}}\right) \times 100 \text { Equation } 1
$$

The NOSCI\% was expressed as SCI50, which is defined as the concentration $(\mu \mathrm{g} / \mathrm{mL})$ of the extract required to scavenge $50 \%$ of NO-.

Hydrogen peroxide: Measurement of hydrogen peroxide scavenging potential was according to the methods of Banerjee et al. [41] but with minor modifications. Separate volumes of $50 \mu \mathrm{L}$ of $1.0 \mathrm{mM} \mathrm{H}_{2} \mathrm{O}_{2}$ and $100 \mu \mathrm{L}$ of various concentrations $(20-80 \mu \mathrm{g} / \mathrm{mL})$ of the extracts were incubated at $25^{\circ} \mathrm{C}$ for $30 \mathrm{~min}$. A $0.85 \mathrm{~mL}$ FOX Reagent $(100 \mu \mathrm{M}$ xylenol orange, $250 \mu \mathrm{M}$ ammonium ferrous sulphate and $25 \mathrm{mM}$ $\mathrm{H}_{2} \mathrm{SO}_{4}$ ) was added to the reaction mixtures and allowed to stand at $25^{\circ} \mathrm{C}$ for $30 \mathrm{~min}$. The absorbance of ferric-xylenol orange complex of the mixtures were measured against a blank at $\lambda_{\max }=560 \mathrm{~nm}$.

The hydrogen peroxide scavenging capacity index (HPSCI) of the extracts was calculated thus:

$$
\text { HPSCI\% }=\left(1-\frac{\text { Absorbance }_{\text {Test }}}{\text { Absorbance }_{\text {Blank }}}\right) \times 100 \text { Equation } 2
$$

The HPSCI\% was expressed as SCI50, which is defined as the concentration $(\mu \mathrm{g} / \mathrm{mL})$ of the extract required to scavenge $50 \%$ of $\mathrm{H}_{2} \mathrm{O}_{2}$.

\section{Hydroxyl radical}

The procedure was carried out as previously described [42] but with minor modification. Briefly, the reaction mixture containing $100 \mu \mathrm{L}$ of
$28 \mathrm{mM}$ 2-deoxyribose, $500 \mu \mathrm{L}$ of various concentrations (20-80 $\mu \mathrm{g} / \mathrm{mL}$ ) of the extracts in phosphate buffer $(\mathrm{pH}=7.4), 200 \mu \mathrm{L}$ of $200 \mu \mathrm{M}$ $\mathrm{FeCl}_{3}$ in $1.04 \mathrm{mM}$ aqueous EDTA $(1: 1, \mathrm{v} / \mathrm{v}), 100 \mu \mathrm{L}$ of $1.0 \mathrm{mM} \mathrm{H}_{2} \mathrm{O}_{2}$, and $100 \mu \mathrm{L}$ of $1.0 \mathrm{mM}$ ascorbic acid was incubated at $37^{\circ} \mathrm{C}$ for $1 \mathrm{~h}$. The reaction was terminated by the addition of $1.0 \mathrm{~mL}$ of $28 \%$ trichloroacetic acid (TCA). A $1.0 \mathrm{~mL}$ of $10 \%$ thiobarbituric acid (TBA) was added and the mixture was again incubated on a water bath at $80^{\circ} \mathrm{C}$ for $20 \mathrm{~min}$. After cooling to $25^{\circ} \mathrm{C}$, the absorbance the mixtures were measured at $\lambda_{\max }=532 \mathrm{~nm}$ against a blank.

The hydroxyl radical scavenging capacity index (HRSCI) of the extracts was calculated thus:

$$
\text { HRSCI\% }=\left(1-\frac{\text { Absorbance }_{\text {Test }}}{\text { Absorbance }_{\text {Blank }}}\right) \times 100 \text { Equation } 3
$$

The HRSCI\% was expressed as SCI50, which is defined as the concentration $(\mu \mathrm{g} / \mathrm{mL})$ of the extract required to scavenge $50 \%$ of $\bullet$ $-\mathrm{OH}$.

\section{Ferric reducing antioxidant power}

The ferric $\left(\mathrm{Fe}^{3+}\right)$ reducing antioxidant power was measured as previously reported [43] but with minor modifications. Equal volumes $(0.5 \mathrm{~mL})$ of various concentrations $(20-80 \mu \mathrm{g} / \mathrm{mL})$ of the extracts and $1.0 \% \mathrm{~K}_{3} \mathrm{Fe}(\mathrm{CN})_{6}$ with $0.2 \mathrm{M}$ phosphate buffer $(\mathrm{pH}=6.6)$ were mixed and incubated at $50^{\circ} \mathrm{C}$ in a water bath for $20 \mathrm{~min}$. TCA $(0.5 \mathrm{~mL})$ was added to the mixture and centrifuged at $3000 \mathrm{rpm}$ for $10 \mathrm{~min}$. Finally, $0.5 \mathrm{~mL}$ of the supernatant was mixed with equal volume of distilled water and $0.1 \mathrm{~mL}$ of $0.1 \% \mathrm{FeCl}_{3}$ solution. The reaction mixture was left to stand at $25^{\circ} \mathrm{C}$ for $10 \mathrm{~min}$ and the absorbance measured at $\lambda_{\max }=700$ $\mathrm{nm}$ against a blank.

The ferric reducing antioxidant power (FRAP) of the extracts was calculated thus:

$$
\text { FRAP\% }=\left(1-\frac{\text { Absorbance }_{\text {Test }}}{\text { Absorbance }_{\text {Blank }}}\right) \times 100 \text { Equation } 4
$$

The FRAP\% was expressed as AP50, which is defined as the concentration $(\mu \mathrm{g} / \mathrm{mL})$ of the extract required to reduce $50 \%$ of $\mathrm{FeCl}_{3}$.

\section{Statistical analysis}

The data collected were analyzed by the analysis of variance (ANOVA) procedure while treatment means were separated by the least significance difference (LSD) incorporated in the statistical analysis system (SAS) package of 9.1 (2006 version). Correlation coefficients were determined using Excel Software (Microsoft, 2010 version).

\section{TPC (mg GAE/g dry sample)}

\begin{tabular}{|l|l|l|l|l|}
\hline SB & SBB1 & SBB2 & SM & MBB1 \\
\hline $2.86 \pm 0.02$ & $0.97 \pm 0.02$ & $1.71 \pm 0.05$ & $1.35 \pm 0.01$ & $0.33 \pm 0.01$ \\
\hline $\begin{array}{l}\text { TPC: } \text { Total Phenolic Content; SB: Soya Bean; SBB1, SBB2: Soya Bean-Based Beverages; MBB1, MBB2: Maize-Based Beverages. The values are mean (X) } \pm \text { S.D of } \\
\text { three }(n=3) \text { determinations. All values of the means are significantly different at } p<0.05 \text { according to LSD. }\end{array}$ \\
\hline
\end{tabular}

Table 2: Total phenolic contents of soya bean and maize and their beverages. 
Page 4 of 7

\section{Results}

Table 2 showed that the TPC of SB, SBB1 and SBB2 was within the range of $0.97 \pm 0.02-2.86 \pm 0.02 \mathrm{mg}$ GAE/g dry sample, in which the $\mathrm{TPC}$ of the samples were in the increasing order: $\mathrm{SB}>\mathrm{SBB} 2>\mathrm{SBB} 1$

Furthermore, the TPC of SM, MBB1 and MBB2 showed significant difference $(\mathrm{p}<0.05)$ and were in the increasing order: $\mathrm{SM}>\mathrm{MBB} 1>\mathrm{MBB} 2$. Overall, the TPC of the various samples showed significant difference $(\mathrm{p}<0.05)$.

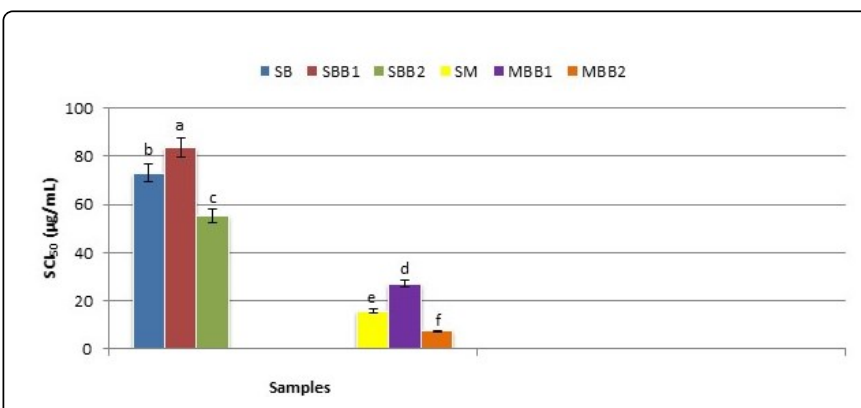

Figure 1: Nitric oxide radicals scavenging capacity indices of soya bean and maize and their beverages. Means denoted by the same letter are not significantly different at $\mathrm{p}>0.05$ according to LSD.

Figure 1 showed that SCI50 of SB against NO- was significantly $(p<0.05)$ lower than that of SBB1. Additionally, SCI50 of SBB2 against $\mathrm{NO}-$ was significantly lower $(\mathrm{p}<0.05)$ than that of $\mathrm{SB}$. In the same order described above, the SCI50 of SM against NO- was significantly lower $(p<0.05)$ than that of MBB1 but significantly higher $(p<0.05)$ than that of MBB2. Generally, Figure 1 showed that SM and its industrial processed products (i.e. MBB1 and MBB2) gave significantly lower $(\mathrm{p}<0.05)$ SCI50 against NO- than those of SB and its industrial processed products (i.e. SBB1 and SBB2).

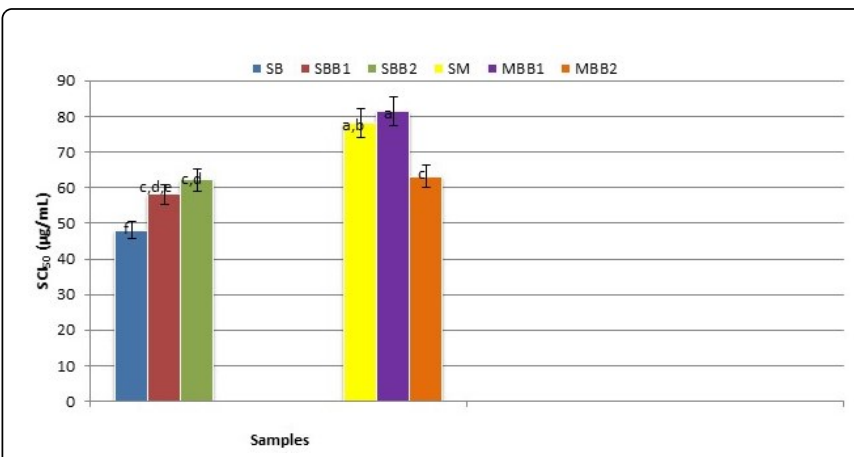

Figure 2: Hydrogen peroxide scavenging capacity indices of soya bean and maize and their beverages. Means denoted by the same letter are not significantly different at $\mathrm{p}>0.05$ according to LSD.

The SCI50 of SB against $\mathrm{H}_{2} \mathrm{O}_{2}$ was significantly lower $(\mathrm{p}<0.05)$ than those of SBB1 and SBB2 (Figure 2). Furthermore, the SCI50 of SBB1 and SBB2 against $\mathrm{H}_{2} \mathrm{O}_{2}$ showed no significant difference $(\mathrm{p}>0.05)$. Conversely, SCI50 of MBB2 against $\mathrm{H}_{2} \mathrm{O}_{2}$ was significantly lower $(\mathrm{p}<0.05)$ than those of SM and MBB1, in which the SCI50 of SM and $\mathrm{MBB} 1$ against $\mathrm{H}_{2} \mathrm{O}_{2}$ showed no significant difference $(\mathrm{p}>0.05)$.

Overall, SCI50 of SB, SBB1 and SBB2 against $\mathrm{H}_{2} \mathrm{O}_{2}$ were significantly lower $(p<0.05)$ than those of $\mathrm{SM}$ and MBB1. However, SCI50 of MBB2 against $\mathrm{H}_{2} \mathrm{O}_{2}$ was not significantly different ( $\left.\mathrm{p}>0.05\right)$ from those of SBB1 and SBB2.

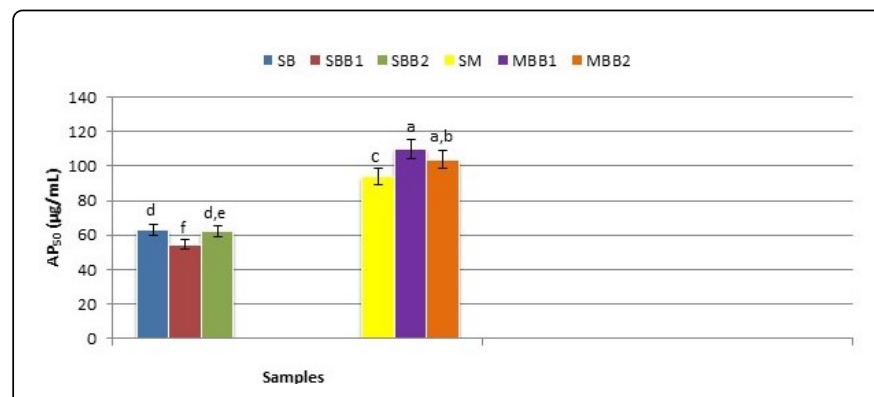

Figure 3: Ferric reducing antioxidant powers of soya bean and maize and their beverages. Means denoted by the same letter are not significantly different at $\mathrm{p}>0.05$ according to LSD.

Figure 3 showed that AP50 of SB was not significantly different ( $>0.05$ ) from that of SBB2; whereas that of SBB1 was significantly lower $(\mathrm{p}<0.05)$ than those of SB and SBB2. Likewise, AP50 of MBB1 and $\mathrm{MBB} 2$ showed no significant difference $(\mathrm{p}>0.05)$ whereas that of SM was significantly lower $(\mathrm{p}<0.05)$ than those of MBB1 and MBB2.

Generally, AP50 of SB, SBB1 and SBB2 were significantly lower $(\mathrm{p}<0.05)$ than those of SM, MBB1 and MBB2.

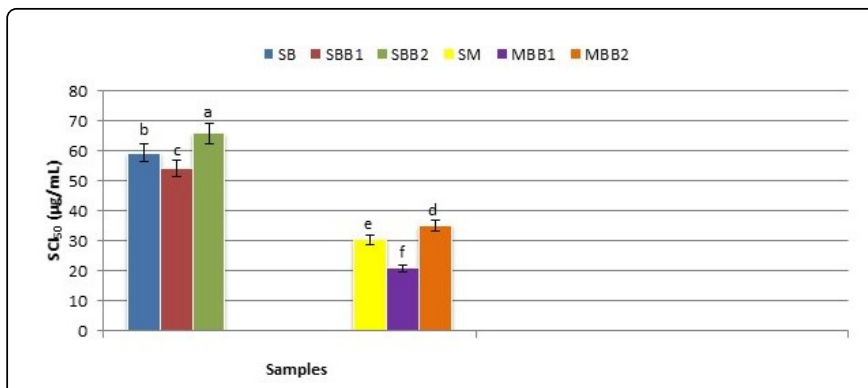

Figure 4: Hydroxyl radicals scavenging capacity indices of soya bean and maize and their beverages. Means denoted by the same letter are not significantly different at $\mathrm{p}>0.05$ according to LSD.

Figure 4 showed that SCI50 of SB, SBB1 and SBB2 against $\bullet-\mathrm{OH}$ were significantly different $(\mathrm{p}<0.05)$ and was in the increasing order: SBB2 $>$ SB $>$ SBB1. Similarly, SCI50 of SM, MBB1 and MBB2 against • $-\mathrm{OH}$ was in the increasing order: $\mathrm{MBB} 2>\mathrm{SM}>\mathrm{MBB} 1 ; \mathrm{p}<0.05$. Overall, SCI50 of SM, MBB1 and MBB2 against $\bullet-\mathrm{OH}$ were significantly lower $(\mathrm{p}<0.05)$ than those of SB, SBB1 and SBB2. 
Page 5 of 7

\begin{tabular}{|c|c|c|}
\hline \multicolumn{3}{|l|}{ Correlation coefficient $(r)$} \\
\hline Parameters & Soya bean and its beverages & Maize and its beverages \\
\hline Nitric oxide radicals & -0.24949 & 0.040672 \\
\hline Hydrogen peroxide & -0.77227 & 0.517909 \\
\hline Ferric reducing antioxidant power & 0.863087 & -0.87017 \\
\hline Hydroxyl radicals & 0.338172 & 0.064258 \\
\hline
\end{tabular}

Table 3: Correlation between total phenolic contents and antioxidant capacity indices of soya bean and maize and their beverages.

The TPC of SB, SBB1 and SBB2 and their corresponding SCI50 against $\mathrm{NO}-, \mathrm{H}_{2} \mathrm{O}_{2}$ and $\bullet-\mathrm{OH}$ gave correlation coefficients between the range: -0.77227 to -0.338172 units (Table 3). Additionally, the TPC of SB, SBB1 and SBB2 and their corresponding AP50 gave a strong positive correlation.

The TPC of SM, MBB1 and MBB2 and their corresponding SCI50 against NO-, $\mathrm{H}_{2} \mathrm{O}_{2}$ and $\bullet-\mathrm{OH}$ gave correlation coefficients between the range: 0.040672-0.51799 units, whereas TPC of SM, MBB1 and MBB2 and their corresponding AP50 showed a strong negative correlation.

\section{Discussion}

The present study showed that SB and SM with their corresponding industrial processed beverages exhibited variations in their TPC, in which TPC of the unprocessed samples were relatively higher than those of their corresponding processed samples (Table 2). Previous studies had reported that the impact of processing and storage of plant foods may alter their comparative TPC, as observed in berry processing where myricetin and kaempferol contents were noted to be more prone to losses than quercetin $[1,44]$. Likewise, processing raw apples of different cultivars into juices and sauces at different temperatures $\left(20-50^{\circ} \mathrm{C}\right)$ caused between $19 \%$ and $53 \%$ losses in TPC in the finished products [45]. The losses or reductions in TPC in the beverages were attributed to commercial processing procedures as previously reported $[3,46,47]$. Aside the impacts of processing and storage on TPC, intrinsic factors like genus, and species and cultivars differences in conjunction with extrinsic factors like agronomic practices, environmental conditions also dictate the TPC of plant foods $[1,3,47,48]$.

Phenolics are powerful antioxidants $[2,5]$ and have been proven to be more potent antioxidants than ascorbic acid, $\alpha$-tocopherol and the carotenoids [3,49]. Earlier reports had shown that the levels of phenolic compounds in plant foods could be a major determinant of their antioxidant potential $[1,50]$. Intuitively, unprocessed samples that contain relatively high TPC ought to exhibit proportionately greater antioxidant activities than their corresponding processed samples, exemplified by the greater capacity of SB to scavenge $\mathrm{H}_{2} \mathrm{O}_{2}$ than SBB1 and SBB2 (Figure 2), which contained comparatively lower TPC (Table 2). Additionally, extracts with relatively high TPC ought to exhibit greater FRAP than those that contained lower TPC (Figure 3). However, the paradox whereby the industrial processed samples, that contained relatively lower TPC, exhibited greater radical scavenging capacities compared with the unprocessed samples was as a result of fortification of the products with antioxidant vitamins $\mathrm{A}, \mathrm{C}$ and $\mathrm{E}$ as indicated in Table 1, which conformed with previous reported $[51,52]$. The relatively wide differentials in correlation coefficients between TPC and antioxidant activities of the various samples, which corroborated previous results [53-55], were obvious indications that non-phenolic antioxidant components acted in synergy with phenolic compounds of the samples at varying capacities in neutralizing the radicals in vitro. According to previous reports, the total antioxidant potential of foodstuffs did not depend on their absolute antioxidants contents but, to a large extent, on the outcomes of synergic and redox interactions among the various radical neutralizing molecules in the products [53,56,57]. Additionally, intrinsic factors such as the molecular configuration of phenolics [4,58] and type of cultivar from which the phenolic compounds are sourced [59-61] as well as the presence of interfering elements and antioxidant antagonist, for the most part, define the antioxidant capacities of phenolic compounds $[54,55]$.

For instance, the capacities of SB, SBB1 and SBB2 to scavenge $\mathrm{H}_{2} \mathrm{O}_{2}$ as well as FRAPs of SM, MBB1 and MBB2 were largely dependent on their TPC as typified by their corresponding strong negative correlations. Conversely, FRAPs of SB, SBB1 and SBB2 were not dictated, to large extent, by their TPC as indicated by the strong positive correlation between their TPC and AP50 (Table 2). Previous reports had noted that in the presence of non-phenolic antioxidants, the antioxidant activities of phenolic compounds were not mutually exclusive but acted in synergy with their co-antioxidants, and phenolic compounds were also involved in the regeneration of essential antioxidant vitamins in biologic systems $[2,62,63]$.

\section{Conclusion}

From general principles and definition, the experimentally derived SCI50 or AP50 are inversely proportional to antioxidant activity of the sample. The in vitro antioxidant systems used in the present study revealed that SB and SM with their beverages exhibited differential FRAP indices as well as antioxidant activities against $\mathrm{NO}-, \mathrm{H}_{2} \mathrm{O}_{2}$ and $-\mathrm{OH}$ and, for the most part, their antioxidant potential was intertwined with the combinatorial antioxidant peculiarities of the various samples. On a point of caution, measurement of antioxidant activities of plant foods applying in vitro models, in many instances, do not always present reproducible outcomes using in vivo evaluation methods. 


\section{Conflict of Interests}

The authors declare that there is no conflict of interest regarding the publication of this article.

\section{Acknowledgement}

The authors are grateful for the technical assistance offered by Mr. O.A.K. Emenyonu, Chief Academic Technologist, Department of Biochemistry, Imo State University, Owerri.

\section{References}

1. Balasundram N, Sundram K, Samman S (2006) Phenolic compounds in plants and agro-industrial by-products: Antioxidant activity, occurrence, and potential uses. Food Chem 99: 191-203.

2. Tsao R (2010) Chemistry and biochemistry of dietary polyphenols Nutrients 2: 1231-1246.

3. Dai J, Mumper RJ (2010) Plant phenolics: extraction, analysis and their antioxidant and anticancer properties. Molecules 15: 7313-7352.

4. Chikezie PC, Ibegbulem CO, Mbagwu FN (2015) Bioactive principles from medicinal plants. Res J Phytochem 9: 88-115.

5. Perron NR, Brumaghim JL (2009) A review of the antioxidant mechanisms of polyphenol compounds related to iron binding. Cell Biochem Biophys 53: 75-100.

6. Erdman JW Jr, Balentine D, Arab L, Beecher G, Dwyer JT, et al. (2007) Flavonoids and heart health: proceedings of the ILSI North America Flavonoids Workshop, Washington, DC. J Nutr 137: 718-737.

7. Pandey KB, Rizvi SI (2009) Plant polyphenols as dietary antioxidants in human health and disease. Oxid Med Cell Longev 2: 270-278.

8. Randhir R, Lin YT, Shetty K (2004) Phenolics, their antioxidant and antimicrobial activity in dark germinated fenugreek sprouts in response to peptide and phytochemical elicitors. Asia Pac J Clin Nutr 13: 295-307.

9. Ramawat KG, Dass S, Mathur M (2009) The chemical diversity of bioactive molecules and therapeutic potential of medicinal plants. In: Herbal drugs: Ethnomedicine to modern medicine. Ramawat KG. (Ed.). Springer-Verlag Berlin Heidelberg.

10. Lila MA (2004) Anthocyanins and Human Health: An In Vitro Investigative Approach. J Biomed Biotechnol 2004: 306-313.

11. Reed JD (1995) Nutritional toxicology of tannins and related polyphenols in forage legumes. J Anim Sci 73: 1516-1528.

12. Chung KT, Wong TY, Wei CI, Huang YW, Lin Y (1998) Tannins and human health: a review. Crit Rev Food Sci Nutr 38: 421-464.

13. Hagerman AE, Riedl KM, Jones GA, Sovik KN, Ritchard NT, et al. (1998) High molecular weight plant polyphenolics (tannins) as biological antioxidants. J Agric Food Chem 46: 1887-1892.

14. Hatano T, Kagawa H, Yasuhara T, Okuda T (1988) Two new flavonoids and other constituents in licorice root: their relative astringency and radical scavenging effects. Chem Pharm Bull 36: 2090-2097.

15. Rodríguez-Ramiro I, Ramos S, López-Oliva E, Agis-Torres A, Bravo L, et al. (2012) Cocoa polyphenols prevent inflammation in the colon of azoxymethane-treated rats and in TNF-a-stimulated Caco- 2 cells. Br J Nutr 28: 1-10.

16. Del Rio D, Rodriguez-Mateos A, Spencer JPE, Tognolini M, Borges G, et al. (2013) Dietary (poly)phenolics in human health: Structures, bioavailability, and evidence of protective effects against chronic diseases. Antioxid Redox Signaling 18: 1818-1892.

17. Bahadoran Z, Mirmiran P, Azizi F (2013) Dietary polyphenols as potential nutraceuticals in management of diabetes: a review. J Diabetes Metab Disord 12: 43.

18. Zhang L, Chang JH, Zhang BQ, Liu XG, Liu P, et al. (2015) The pharmacokinetic study on the mechanism of toxicity attenuation of rhubarb total free anthraquinone oral colon-specific drug delivery system. Fitoterapia 104: 86-96.
19. Multilingual Multi-script (2012) Glycine max. Multilingual multi-script plant name database.

20. USDA (2014) United State Department of Agriculture. Nutrient data laboratory.

21. Yamori Y (2006) Do diets good for longevity really exist? Lessons from the eating habits of countries with long-lived populations. J Jap Med Assoc 52: 17-22.

22. Masuda T, Goldsmith PD (2009) World soybean production: Area harvested, yield, and long-term projections. Int Food Agribusiness Manag Rev 12: 143-162.

23. Jaiswal A (2009) Economics of production and value addition to soybean in Madhya Pradesh. MSc in Agriculture Thesis. University of Agricultural Sciences, Dharwad.

24. Endres JG (2001) Soy protein products: Characteristics, nutritional aspects, and utilization. AOCS Press. USA.

25. Hoogenkamp HW (2005) Soy protein and formulated meat products. CABI publishers. Willingford, Ovon, UK.

26. Chandiposha M, Ignatius C, Veronica M (2013) Utilization of common grain crops in Zimbabwe. Afr J Food Sci 7: 253-257.

27. CRC (1983) CRC handbook of naturally occurring food toxicants. CRC Press, Boca Raton, FL, USA.

28. Liener IE (1996) Soybean protease inhibitors and pancreatic carcinogenesis. J Nutr 126: 582-585.

29. FAO (2015) Rome, Italy: Food and Agriculture Organization of the United Nations.

30. Ranum P, Peña-Rosas JP, Garcia-Casal MN (2014) Global maize production, utilization, and consumption. Ann N Y Acad Sci 1312: 105-112.

31. FAO (2009) Agribusiness handbook: Wheat flour. FAO. Rome, Italy.

32. FAO (2012) Agricultural statistics. Food and Agricultural Organization of the United Nations. Rome.

33. IGC (2013) International grain council market report 28 for November 2013.

34. He F, Liang NN, Mu L, Pan QH, Wang J, et al. (2012) Anthocyanins and their variation in red wines I. Monomeric anthocyanins and their color expression. Mol 17: 1571-160.

35. King A, Young G (1999) Characteristics and occurrence of phenolic phytochemicals. J Am Diet Assoc 99: 213-218.

36. Hunter P (2008) Harnessing Nature's wisdom. Turning to Nature for inspiration and avoiding her follies. EMBO Rep 9: 838-840.

37. Ojiako OA, Chikezie PC, Ogbuji AC (2015) Radical scavenging potentials of single and combinatorial herbal formulations in vitro. J Tradit Complement Med 6: 153-159.

38. Suanarunsawat T, Ayutthaya WDN, Thirawarapan S, Poungshompoo S (2014) Anti-oxidative, anti-hyperglycemic and lipid-lowering effects of aqueous extracts of Ocimum sanctum L. leaves in diabetic rats. Food Nutr Sci 5: 801-811.

39. Kumar V, Hussain PR, Chatterjee S, Variyar PS (2015) Evaluation of in vitro antioxidant activity and characterization of phenolic compounds of bottle gourd towards the green synthesis of gold nanoparticles and its bioefficacy. Int J Food Nutr Safety 6: 125-149.

40. Isfahlan AJ, Mahmoodzadeh J, Hassanzadeh A, Heidari R, Jamei R (2010) Antioxidant and antiradical activities of phenolic extracts from Iranian almond (Prunus amygdalus L.) hulla and shells. Turk J Biol 34: 165-173.

41. Banerjee D, Madhusoodanan UK, Sharanabasappa M, Ghosh S, Jacob J (2003) Measurement of plasma hydroperoxide concentration by FOX-1 assay in conjunction with triphenylphosphine. Clin Chim Acta 337: 147-152.

42. Elizabeth K, Rao MNA (1990) Oxygen radical scavenging activity of curcumin. Int J Pharm 58: 237-240.

43. Oyaizu M (1986) Studies on products of browning reaction: Antioxidative activity of products of browning reaction prepared from glucosamine. Jap J Nutr 44: 307-315 
44. Hakkinen SH, Karenlampi SO, Mykkanen HM, Heinonen IM, Torronen AR (2000) Ellagic acid content in berries: Influence of domestic processing and storage. Eur Food Res Technol 212: 75-80.

45. Markowski J, Plocharski W (2006) Determination of phenolic compounds in apples and processed apple products. J Fruit Ornam Plant Res 14: 133-142.

46. Spanos GA, Wrolstadt RE, Heatherbell DA (1990) Influence of processing and storage on the phenolic composition of apple juice. J Agric Food Chem 38: 1572-1579.

47. Klein BP, Kurilich AC (2000) Processing effects on dietary antioxidants from plant foods. Hortsci 35: 580-584.

48. Tomás-Barberán FA, Espín JC (2001) Phenolic compounds and related enzymes as determinants of quality in fruits and vegetables. J Sci Food Agric 81: 853-876.

49. Rice-Evans CA, Miller NJ, Bolwell PG, Bramley PM, Pridham JB (1995) The relative antioxidant activities of plant-derived polyphenolic flavonoids. Free Radic Res 22: 375-383.

50. Parr AJ, Bolwell GP (2000) Phenols in the plant and in man. The potential for possible nutritional enhancement of the diet by modifying the phenols content or profile. J Sci Food Agric 80: 985-1012.

51. Oboh HA, Omoregie IP (2011) Total phenolics and antioxidant capacity of some Nigerian beverages. Nig J Basic Appl Sci 19: 68-75.

52. Paul P, Bhattacharyya S (2015) Antioxidant profile and sensory evaluation of cookies fortified with juice and peel powder of fresh Pomegranate (Punica granatum). Int J Agric Food Sci 5: 85-91.

53. Gawlik-Dziki U (2012) Changes in the antioxidant activities of vegetables as a consequence of interactions between active compounds. J Funct Foods 4: 872-882.

54. Saeed N, Khan M, Shabbir M (2012) Antioxidant activity, total phenolic and total flavonoid contents of whole plant extracts Torilis leptophylla L. BMC Comple Altern Med 12: 221
55. Jing L, Ma H, Fan P, Gao R, Jia Z (2015) Antioxidant potential, total phenolic and total flavonoid contents of Rhododendron anthopogonoides and its protective effect on hypoxia-induced injury in PC12 cells. BMC Compl Alter Med 15: 287.

56. Ramadan MF, Kroh LW, Moersel JT (2003) Radical scavenging activity of black cumin (Nigella sativa L.), coriander (Coriandrum sativum L.) and niger (Guizotia abyssinica Cass.) crude seed oils and oil fractions. J Agric Food Chem 51: 6961-6969.

57. Ramadan MF, Moersel JT (2007) Impact of enzymatic treatment on chemical composition, physicochemical properties and radical scavenging activity of goldenberry (Physalis peruviana L.) juice. J Sci Food Agric 87: 452-460.

58. Statue-Gracia MT, Heionen M, Frankel EN (1997) Antioxidant activity of anthocyanin in LDL and lecithin liposome systems. J Agric Food Chem 5: 3362-3367.

59. Ehlenfeldt MK, Prior RL (2001) Oxygen radical absorbance capacity (ORAC) and phenolic and anthocyanin concentrations in fruit and leaf tissues of highbush blueberry. J Agric Food Chem 49: 2222-2227.

60. Prior RL, Cao G, Martin A, Sofic E, McEwen J, et al. (1998) Antioxidant capacity as influenced by total phenolic and anthocyanin content, maturity, and variety of Vaccinium species. J Agric Food Chem 46: 2686-2693.

61. Jiao H, Wang SY (2000) Correlation of antioxidant capacities to oxygen radical scavenging enzyme activities in blackberry. J Agric Food Chem 48: 5672-5676.

62. Zhou B, Wu LM, Yang L, Liu ZL (2005) Evidence for alpha-tocopherol regeneration reaction of green tea polyphenols in SDS micelles. Free Radic Biol Med 38: 78-84.

63. Alok S, Jain SK, Verma A, Kumar M, Mahor A, et al. (2014) Herbal antioxidant in clinical practice: a eview. Asian Pac J Trop Biomed 4: 78-84. 